\title{
ANALISIS PENGARUH INVESTASI, MODAL DAN UPAH TERHADAP PENYERAPAN TENAGA KERJA PADA INDUSTRI ANYAMAN ROTAN DI KOTA PALANGKA RAYA
}

\author{
Febriani Silitonga $^{1}$, Sunaryo Neneng ${ }^{2 *}$, Dedi Takari ${ }^{3 *}$ \\ 1,2,3 Fakultas Ekonomi dan Bisnis, Universitas Palangka Raya \\ Corresponding: sunaryo.tuah65@gmail.com, detakari@gmail.com
}

\begin{tabular}{|c|c|}
\hline CHRONICLE & ABSTRACT \\
\hline $\begin{array}{l}\text { Article History: } \\
\text { Received: Nopember } 1 \text {, } \\
2020 \\
\text { Revised: December 2020, } \\
\text { January 2021 } \\
\text { Accepted: Februari 2, } \\
2021\end{array}$ & $\begin{array}{l}\text { Research on the speed of development economic growth in the rattan wicker industry } \\
\text { during the COVID-19 pandemic aims to analyze that the value of capital investment and } \\
\text { wages has a significant effect on labor absorption in the rattan woven industry in the city } \\
\text { of Palangka Raya. The benefits of this research can add knowledge and insight, especially } \\
\text { how the industrial development of rattan woven in Palangka Raya City. The data used in } \\
\text { this study are primary data and data collection was done by interviewing } 25 \text { respondents, } \\
\text { the data that had been collected were processed and analyzed using multiple linear }\end{array}$ \\
\hline $\begin{array}{l}\text { Keywords : } \\
\text { Investment, Capital, } \\
\text { Wages, Labor, Wicker } \\
\text { Rattan }\end{array}$ & $\begin{array}{l}\text { regression. The results showed that the added value of investment, wages and capital } \\
\text { together up to a confidence level of } 80 \% \text { had a significant effect on the employment of the } \\
\text { rattan weaving industry in Palangka Raya City. In terms of the investment value variable, } \\
\text { every time there is an increase in investment value of } 1 \% \text {, it can cause the increase in labor } \\
\text { absorption to be } 8.275 \% \text {. Every } 1 \% \text { increase in the value of capital can cause the increase } \\
\text { in labor absorption by } 3.351 \% \text {. Each } 1 \% \text { increase in the value of wages can cause the } \\
\text { increase in labor absorption by } 1.987 \% \text {. For the handicraft industry in taking the given } \\
\text { capital assistance, it is better to pay attention to the management of that capital. The need } \\
\text { for financial records must also be considered so that there is transparency to various } \\
\text { parties regarding capital and income. So that this research can be a reference in further } \\
\text { research regarding the rate of economic growth which has an impact on other handicraft } \\
\text { industries in Indonesia, so that this business remains sustainable. }\end{array}$ \\
\hline
\end{tabular}

\section{Latar Belakang}

Industrialisasi salah satu tujuannya adalah untuk dapat menyerap tenaga kerja yang semakin meningkat dengan semakin tingginya laju pertumbuhan penduduk. Perluasan penyerapan tenaga kerja diperlukan untuk mengimbangi laju pertumbuhan penduduk usia muda yang masuk ke pasar tenaga kerja. Ketidak seimbangan antara pertumbuhan angkatan kerja dan penciptaan lapangan kerja akan menyebabkan tingginya angka pengangguran. Kemudian, meningkatnya angka pengangguran akan mengakibatkan pemborosan sumber daya dan potensi angkatan kerja yang ada, meningkatnya beban masyarakat, merupakan sumber utama kemiskinan dan mendorong terjadinya peningkatan keresahan sosial, serta manghambat pembangunan ekonomi dalam jangka panjang $[1,2]$. Stok modal atau investasi merupakan salah satu faktor penting dalam menentukan tingkat pendapatan nasional. Kegiatan investasi memungkinkan suatu masyarakat terus menerus meningkatkan kegiatan ekonomi dan kesempatan kerja, meningkatkan pendapatan nasional dan taraf kemakmuran [3,2]. Adanya investasi-investasi akan mendorong terciptanya barang modal baru sehingga akan menyerap factor produksi baru yaitu menciptakan lapangan kerja baru atau kesempatan kerja yang akan menyerap tenaga yang pada gilirannya akan mengurangi pengangguran [1].

Secara teoritis, semakin besar nilai investasi yang dilakukan maka semakin besar pula tambahan penggunaan tenaga kerja [4,5-8]. Selain investasi, faktor yang seringkali menjadi permasalahan dalam ketenagakerjaan adalah yang berkaitan dengan upah. Permintaan tenaga kerja memiliki hubungan antara tingkat upah dan kuantitas tenaga kerja yang dikehendaki untuk dipekerjakan dalam jangka waktu tertentu. Penentuan besarnya upah minimum menjadi salah satu faktor yang berkaitan dengan kemampuan dari masing-masing usaha industri $[3,7]$. Industri rumahan merupakan salah satu sektor yang menarik untuk diperhatikan, selain perkembangan dan persebaran yang pesat sehingga terjadi perubahan dinamika pada industri tersebut. Industri rumahan memiliki peran besar dalam menyokong perekonomian masyarakat. Dalam perkembangannya industri rumahan mampu bertahan disebabkan mercepat respon akan perubahan dan pemanfaatan sumber daya alam sebagai bahan baku utama. Industri rumahan termasuk kegiatan industri yang berskala kecil namun menggeliat akhirakhir ini. Departemen Perindustrian dan perdagangan menjelaskan industri rumahan sebagai kegiatan usaha yang memiliki nilai investasi sampai Rp. 200.000.000 (dua ratus juta rupiah) tidak termasuk dengan tanah dan bangunan tempat usaha [4,6]. Definisi ndustri secara umum sebagai kegiatan ekonomi yang mengolah bahan baku, bahan mentah, barang setengah jadi dan barang jadi menjadi barang dengan nilai yang lebih tinggi lagi penggunaannya. Di Indonesia, industri rumahan termasuk salah satu jenis industri yang banyak digeluti oleh masyarakat [1,5]. Selain karena faktor modal usaha, keterampilan dan keahliaan juga karena ketersediaan bahan baku yang melimpah. Pada dasarnya terdapat beberapa jenis industri rumahan yang digarap masyarakat 
diantaranya meliputi industri makanan dan minuman, industri tekstil, industri kayu dan kerajinan rotan.

Salah satu jenis industri rumahan yang cukup potensial dan cukup banyak digeluti masyarakat adalah industri rotan. Hal ini disebabkan karena Indonesia merupakan Negara penghasil rotan terbesar di Asia dan produksinya sudah mengisi pasar pasar dunia dan ini menjadi bukti betapa kuatnya perkembangan industri rumahan rotan di Indonesia. Industri kerajinan rotan tidak hanya dijumpai di wilayah pedesaan namun juga wilayah perkotaan. Hampir setiap Kota di Indonesia memiliki sentra kerajinan rotan, Di Provinsi Kalimantan tengah sendiri juga terdapat sentral kerajinan rotan di wilayah Kota yakni di Kota Palangka Raya. Kota Palangka Raya sebagai Ibu Kota Provinsi Kalimantan Tengah memiliki potensi yang cukup besar dalam usaha industri kerajinan Rotan. Kerajinan berbahan rotan bukanlah sesuatu yang mudah untuk diolah sehingga menghasilkan barang-barang yang sangat mengangumkan dan bernilai jual tinggi.

Berawal dari jenis bahan baku yang digunakan pengrajin rotan, para pengrajin mengeluhkan mahalnya harga bahan baku dengan kualitas tinggi yang mereka peroleh dari luar daerah. Adanya hubungan kerjasama tersebut didasari atas rasa kepercayaan sehingga menghasilkan suatu jaringan dalam menjaga hubungan serta keberlansungan usaha kerajinan rotan. Pemaparan yang menjelaskan tentang persaingan yang terjadi dalam usaha kerajinan rotan terkhusus membahas tentang pemasaran hasil kerajinan rotan yang sama, maka modal pengrajin dalam menjalankan dan mempertahankan usaha kerajinan rotan. Berdasarkan latar belakang tersebut, maka penulis tertarik meneliti tentang "Pengaruh Investasi Modal Upah Terhadap Penyerapan Tenaga Kerja Pada Industri Anyaman Rotan Di Palangka Raya”

\section{Tinjauan Pustaka}

Industri adalah suatu unit atau kesatuan produksi yang terletak pada suatu tempat tertentu yang melakukan kegiatan ekonomi, bertujuan untuk mengubah suatu barang serta mekanik, kimia, atau dengan tangan, sehingga menjadi benda, barang, atau produk baru yang nilainya lebih tinggi, dan sifatnya lebih dekat kepada konsumen akhir. Perusahaan atau usaha industri merupakan suatu unit kesatuan usaha yang melakukan kegiatan ekonomi, bertujuan menghasilkan barang atau jasa, dan memiliki catatan administrasi tersendiri mengenai produksi dan struktur biaya serta ada yang bertanggung jawab atas usaha tersebut $[3,4-7,16]$.

Menurut simposium hukum perindustrian, yang dimaksud dengan industri adalah rangkaian kegiatan usaha ekonomi yang meliputi pengolahan dan pengerjaan atau pembuatan, perubahan dan perbaikan bahan baku menjadi barang sehingga pada akhirnya akan lebih berguna dan bermanfaat bagi seluruh masyarakat $[1,5]$. Industri adalah suatu unit (kesatuan) usaha yang melakukan kegiatan ekonomi, bertujuan menghasilkan 11 barang atau jasa, dan terletak pada suatu bangunan atau suatu lokasi tertentu serta mempunyai catatan administrasi tersendiri mengenai produksi dan struktur biayanya $[4,6,8]$. Dalam teori ekonomi disebutkan bahwa industri merupakan kumpulan dari perusahaan-perusahaan yang menghasilkan barang yang sama. Industri dapat diklasifikasikan menjadi beberapa jenis, yaitu berdasarkan bahan baku, tenaga kerja, produksi yang dihasilkan, bahan mentah, lokasi unit usaha, proses produksi barang yang dihasilkan,modal yang digunakan, subjek pengelola, dan cara pengorganisasian. Berikut beberapa jenis klasifikasinya :

\subsection{Industri Berdasarkan Bahan Baku}

Berdasarkan bahan baku yang digunakan, industri dibagi menjadi tiga jenis, yaitu: (1). Industri Ekstraktif, yaitu industri yang bahan baku nya diperoleh langsung dari alam. Misalnya industri pertanian, hasil perikanan, dan kehutanan. (2). Industri Non ekstraktif, yaitu industri yang mengolah lebih lanjut hasil hasil-hasil industri lain. Misalnya industri kayu lapis, industri pemintalan, dan industri kain. (3). Industri Fasilitatief atau disebut juga dengan industri tersier, yaitu industri yang kegiatan industrinya adalah dengan menjual jasa layanan untuk keperluan orang lain. Misalnya perbankan, perdagangan, angkutan, dan pariwisata $[7,9]$.

\subsubsection{Industri Berdasarkan Tenaga Kerja}

Berdasarkan jumlah tenaga kerja yang digunakan, industri dapat dibedakan menjadi empat jenis, yaitu: (1) Industri Rumah Tangga, yaitu industri yang menggunakan tenaga kerja kurang dari empat orang. Industri ini memiliki modal yang sangat terbatas, tenaga kerja adalah anggota keluarga, dan pemilik juga pengelola industri biasanya kepala rumah tangga itu sendiri. Contoh : industri anyaman, industri kerajinan, industri tempe, industri tahu, dan industri makanan ringan. (2) Industri kecil, yaitu industri yang tenaga kerjanya berjumlah sekitar 5 sampai 19 orang. Ciri industri kecil adalah memiliki modal yang relatif kecil, tenaga kerja berasal dari lingkungan sekitar ataupun saudara. Misalnya industri genteng, industri batu bata, industri pengolahan rotan.(3) Industri sedang, yaitu industri yang menggunakan tenaga kerja sekitar 20-99 orang. Ciri industri ini adalah memiliki modal yang cukup besar, tenaga kerja memiliki keterampilan tertentu, dan pimpinan perusahaan memiliki kemampuan manajerial tertentu. Misalnya industri konveksi, industri bordir, dan industri keramik. 
(4) Industri besar, yaitu industri dengan jumlah tenaga kerja lebih dari 100 orang. Ciri industri ini adalah memiliki modal besar yang dihimpun dalam bentuk pemilikan saham, tenaga kerja harus memiliki keterampilan khusus, dan pimpinan perusahaan dipilih melalui uji kemampuan dan kelayakan. Misalnya industri tekstil, industri besi baja, dan industri pesawat terbang [8].

\subsubsection{Industri Berdasarkan Produk yang Dihasilkan}

Berdasarkan produk yang dihasilkan, industri dapat dibedakan menjadi tiga jenis, yaitu: (1) Industri primer, yaitu industri yang menghasilkan barang atau benda yang tidak perlu pengolahan lebih lanjut. Barang atau benda tersebut dapat dinikmati atau digunakan secara langsung. Misalnya industri anyaman, konveksi, makanan dan minuman. (2) Industri sekunder, yaitu industri yang menghasilkan barang atau benda yang membutuhkan pengolahan lebih lanjut sebelum dinikmati atau digunakan. Misalnya industri pemintalan benang, industri ban, industri baja, dan industri tekstil. (3) Industri tersier, yaitu industri yang hasilnya tidak berupa barang atau benda yang dinikmati atau digunakan baik secara langsung maupun secara tidak langsung, melainkan berupa jasa layanan yang dapat mempermudah atau membantu kebutuhan masyarakat $[3,7,11]$.

\subsubsection{Industri Berdasarkan Bahan Mentah}

Berdasarkan bahan mentah yang digunakan, industri dapat dibedakan menjadi tiga jenis, yaitu: (1) Industri pertanian, yaitu industri yang mengolah bahan mentah yang diperoleh dari hasil kegiatan pertanian. Misalnya industri minyak goreng, industri gula, industri kopi, industri teh, dan makanan. (2) Industri pertambangan, yaitu industri yang mengolah bahan mentah yang berasal dari hasil pertambangan. Misalnya industri semen, industri baja, industri BBM. (3) Industri Jasa, yaitu industri yang mengolah jasa layanan yang dapat mempermudah dan meringankan beban masyarakat tetapi menguntungkan. Misalnya industry perbankan industri perdagangan, pariwisata,transportasi,seni dan hiburan $[8,9,12]$.

\subsubsection{Industri berdasarkan Lokasi Unit Usaha}

Berdasarkan pada lokasi unit usahanya, industri dapat dibedakan menjadi empat jenis, yaitu: (1) Industri berorientasi pada pasar, yaitu industri yang didirikan dekat dengan keberadaan konsumen atau pasar. (2) Industri yang berorientasi pada pengolahan, yaitu industri yang didirikan dekat atau ditempat pengolahan. (3) Industri berorientasi pada bahan baku, yaitu industri yang didirikan ditempat tersedianya bahan baku. Misalnya industri konveksi berdekatan dengan industri tekstil. (4) Industri yang tidak terikat dengan persyaratan yang lain, yaitu industri yang didirikan tidak terikat dengan syarat-syarat di atas [6]. Berikutnya kerangka pemikiran yang dibangun dalam penelitian ini ialah :

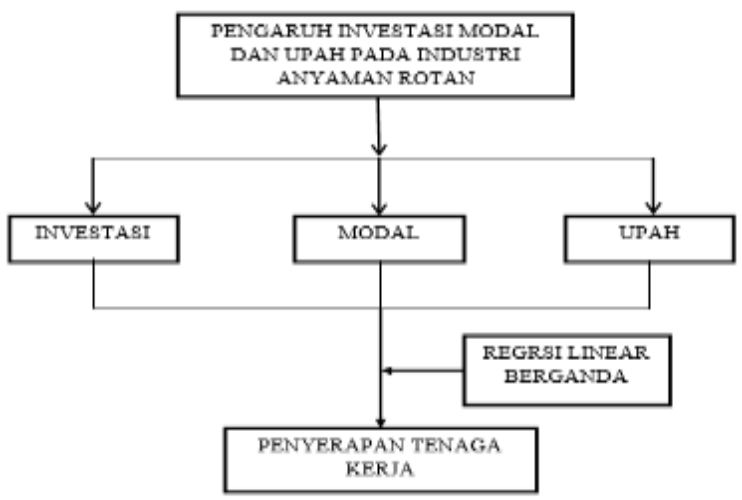

\subsection{Investasi}

Gambar 1. Kerangka Pikir Penelitian (sumber : penulis)

Investasi adalah suatu istilah dengan beberapa pengertian yang berhubungan dengan keuangan dan ekonomi. Istilah tersebut berkaitan dengan akumulasi suatu bentuk aktiva dengan suatu harapan mendapatkan keuntungan dimasa depan $[5,8,13]$. Terkadang, investasi disebut juga sebagai penanaman modal. Berdasarkan teori ekonomi, investasi berarti pembelian (dan berarti juga produksi) dari kapital/modal barang-barang yang tidak dikonsumsi tetapi digunakan untuk produksi yang akan datang (barang produksi). Contoh termasuk membangun rel kereta api, atau suatu pabrik, pembukaan lahan, atau seseorang sekolah di universitas. Untuk lebih jelasnya, investasi juga adalah suatu komponen dari PDB dengan rumus $\mathrm{PDB}=\mathrm{C}+\mathrm{I}+\mathrm{G}+(\mathrm{X}-\mathrm{M})$. Fungsi investasi pada aspek tersebut dibagi pada investasi non- residential (seperti pabrik, mesin, dll) dan investasi residential (rumah baru). Investasi adalah suatu fungsi pendapatan dan tingkat bunga, dilihat dengan kaitannya $\mathrm{I}=(\mathrm{Y}, \mathrm{i})$. Suatu pertambahan pada pendapatan akan mendorong investasi yang lebih besar, dimana tingkat bunga 
yang lebih tinggi akan menurunkan minat untuk investasi sebagaimana hal tersebut akan lebih mahal dibandingkan dengan meminjam uang. Walaupun jika suatu perusahaan lain memilih untuk menggunakan dananya sendiri untuk investasi, tingkat bunga menunjukkan suatu biaya kesempatan dari investasi dana tersebut daripada meminjamkan untuk mendapatkan bunga. Berdasarkan literatur dan penelitian terdahulu maka diajukan hipotesis 1: Adanya pengaruh signifikan dan positif nilai investasi terhadap penyerpan tenaga kerja.2.3 Industri Berdasarkan Modal yang Digunakan

Berdasarkan modal yang digunakan, industri dapat dibedakan menjadi tiga jenis, yaitu: (1) Industri dengan penanaman modal dalam negeri, yaitu industri yang mendapat dukungan modal dari pemerintah atau pengusaha nasional [10]. Misalnya industri pariwisata. (2) Industri dengan penanaman modal asing, yaitu industri yang modalnya berasal dari penanaman modal asing. Misalnya industri komunikasi, industri perminyakan. (3) Industri dengan modal patungan, yaitu industri yang modalnya berasal dari hasil kerja sama antara PMDN dan PMA. Misalnya industri automotif. Faktor Penunjang Pertumbuhan Industri dalam setiap usaha mempunyai dan selalu berusaha untuk memadukan empat faktor produksi yang mendasar yang terdiri dari : (1) Alam, meliputi sumber material yang disediakan oleh alam seperti bahan mentah, tempat untuk mendirikan bangunan dan sebagainya. (2) Modal, merupakan barang atau uang yang digunakan untuk mencapai tujuan produksi. (3) Tenaga kerja, meliputi sumber tenaga (energi) untuk industri dan tenaga kerja untuk proses produksi. (4) Keterampilan, yaitu kemampuan pengusaha dalam mengelola tata laksana usaha yang terdiri dari kepribadian, pengaturan waktu, pengetahuan, ketrampilan tekhnik dan sebagainya $[1,10,15]$. Pembangunan sektor industri dipengaruhi oleh beberapa faktor penunjang yaitu: Tersedianya bahan mentah atau bahan baku, bahan bakar atau energi, pasar dan sarana untuk menjamin permintaan pasar dengan cepat, tenaga kerja yang terampil dalam industri yang bersangkutan [11-16]. Berdasarkan dari beberapa literature maka hipotesis yang diajukan hipotesis 2 : Adanya Pengaruh modal terhadap penyerapan tenaga kerja dan Hipotesis 3 ialah : Adanya pengaruh upah terhadap penyerapan tenaga kerja.

\section{Metode Penelitian}

Teknik pengumpulan data dalam penelitian ini dengan studi pendahuluan untuk menemukan yang diteliti, dan juga apa bila peneliti ingin mengetahui hal-hal dari responden yang lebih mendalam dan jumlah respondennya kecil/ sedikit $[1,7,11,15]$. Teknik wawancara awal yang dilakukan peneliti melakukan tanya jawab secara langsung kepada pihak yeng berwenang. Keterangan yang diberikan oleh responden yaitu besarnya nilai investasi, modal dan upah dan jumlah tenaga kerja yang dapat dijadikan data dan kemudian dicatat secara garis besar sekaligus digunakan sebagai pedoman selama berlangsungnya wawancara [3,7-16]. Dan untuk mempermudah dalam pengumpulan data maka dilakukan Teknik Kuesioner merupakan teknik pengumpulan data yang efisien bila peneliti tahu dengan pasti variabel yang akan diukur dan tahu apa yang bisa diharapkan dari responden. Metode pengumpulan data dengan menggunakan metode kuesioner dengan menggunakan daftar pertayaan (angket)sebagai penentu bagi peneliti untuk melakukan wawancara agar dapat memperoleh data yaitu besarnya nilai investasi, modal dan upah dan jumlah tenaga kerja. Untuk mempermudah dalam pengumpulan sampai analisis data maka dibuatlah kerangka penelitian yang menjadi acuan, sebagai berikut:

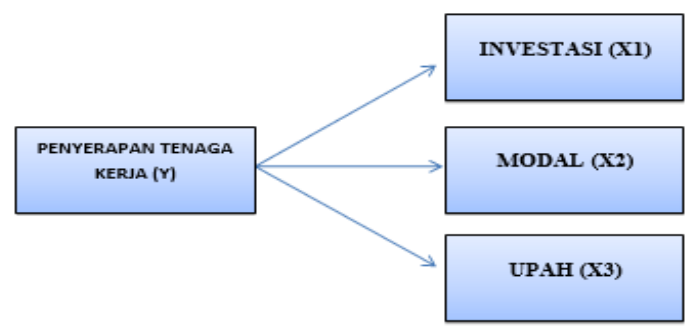

Gambar 2. Kerangka Penelitian

Penelitian ini menggunakan program SPSS untuk menjawab hipotesis dengan regresi Linier Berganda, yang bertujuan menganalisis bagaimana pengaruh investasi, modal, upah dalam penyerapan tenaga kerja. selain itu alat ini dimaksudkan untuk mengetahui ada tidaknya hubungan pengaruh antara variabel yang dijelaskan (variabel terikat) dimana dalam hal ini adalah penyerapan tenaga kerja, dengan variabel yang menjelaskan (variabel bebas) yang dalam hal ini adalah besarnya nilai investasi, modal, upah pada Industri kerajinan annyaman rotan di kota Palangka Raya. 
$\mathrm{Y}=\mathrm{b} 0+\mathrm{b}_{1} X_{1}+\mathrm{b}_{2} X_{2}+\mathrm{b}_{3} X_{3}+\mathrm{e}$

Keterangan:

b0 $=$ Konstanta

$\mathrm{Y}=$ Penyerapan tenaga kerja

$X_{1}=$ Investasi (dalam Rupiah)

$X_{2}=$ Modal (dalam Rupiah)

$X_{3}=\operatorname{Upah}$ (dalam Rupiah).

$\mathrm{b}_{1}=$ Koefisien regresi untuk investasi (Rupiah)

$\mathrm{b}_{2}=$ Koefisien regresi untuk modal (Rupiah) $\mathrm{b}_{3}=$ Koefisien regresi untuk upah (Rupiah)

$\mathrm{e}=$ Variabel pengganggu ( error)

\section{Hasil penelitian}

Analisis Regresi Linear Berganda digunakan untuk mengetahui hubungan antara variabel bebas dan variabel terikat yaitu: nilai investasi, modal, upah, pada penyerapan tenaga kerja. selain itu untuk mengetahui sejauh mana besarnya pengaruh antara variabel bebas dan variabel terikat. Analisi regresi linear berganda menggunakan program SPSS 20. Analisis regresi linear berganda tersaji dalam tabel berikut untuk mempermudah pembaca dalam membaca hasil regresi pada tabel 4.1 sebagai berikut.

\section{Tabel 4.1. Hasil Regresi Linier Berganda}

\begin{tabular}{|c|c|c|c|c|c|}
\hline & \multicolumn{3}{|c|}{ Coefficients ${ }^{\mathrm{a}}$} & \multirow{3}{*}{ T-hitung } & \multirow{3}{*}{ Sig. } \\
\hline \multirow[t]{2}{*}{ Model } & Unstandardized Coeffi & cients & $\begin{array}{l}\text { Standardized } \\
\text { Coefficients }\end{array}$ & & \\
\hline & $\mathrm{B}$ & Std. Error & Beta & & \\
\hline (Constant) & -2.727 & 1.025 & & -2.661 & .015 \\
\hline $\mathrm{X} 1$ & 8.275 & .000 & .354 & 2.258 & .035 \\
\hline $\mathrm{X} 2$ & 3.351 & .000 & .448 & 3.193 & .004 \\
\hline $\mathrm{X} 3$ & 1.987 & .000 & .278 & 2.481 & .022 \\
\hline
\end{tabular}

a. Dependent Variable: Y (sumber : data diolah)

Berdasarkan pada hasil koefisien regresi $(\beta)$ pada tabel 4.1, diperoleh persamaan sebagai berikut: $\mathrm{Y}=-2.727+$ $8.275 X_{1}+3.351 X_{2}+1.987 X_{3}$

Dari hasil persamaan regresi tersebut dapat di simpulkan sebagai berikut:

a. Nilai konstanta sebesar - 2.727 , berarti jika variabel investasi, modal dan upah bernilai 0 , maka penyerapan tenaga kerja akan bernilai - 2.727

b. Nilai koefisien $\beta_{1}$ sebesar 8.275 hal ini menunjukkan bahwa jika terjadi kenaikan pada nilai investasi sebesar Rp.1 maka penyerapan tenaga kerja akan mengalami kenaikan sebesar 2.258 dengan asumsi variabel modal $\left(X_{2}\right)$ dan upah $\left(X_{3}\right)$ dianggap konstan.

c. Nilai koefisien $\beta_{2}$ sebesar 3.351 hal ini menunjukkan bahwa jika terjadi kenaikan pada modal sebesar Rp.1 maka penyerapan tenaga kerja akan mengalami kenaikan sebesar 3.193 dengan asumsi variabel nilai investasi $\left(X_{1}\right)$ dan upah $\left(X_{3}\right)$ dianggap konstan.

d. Nilai koefisien $\beta_{3}$ sebesar 1.987 hal ini menunjukkan bahwa jika terjadi kenaikan pada upah sebesar Rp.1 maka penyerapan tenaga kerja akan mengalami penurunan sebesar 2.481 dengan asumsi variabel nilai investasi $\left(X_{1}\right)$ dan modal $\left(X_{2}\right)$ dianggap konstan.

\subsection{Hasil Uji Hipotesis}

Pengujian secara parsial (t), uji ini digunakan untuk menguji kemaknaan parsial, dengan menggunakan uji t, apabila nilai probabilitas $<\alpha=5 \%$ maka Ho ditolak, dengan demikian variabel bebas dapat menerangkan variabel terikat yang ada dalam model. Sebaliknya apabila nilai probabilitas $>\alpha=5 \%$ maka Ho 
diterima, dengan demikian variabel bebas tidak dapat menjelaskan variabel terikatnya atau dengan kata lain tidak ada pengaruh antara dua variabel yang diuji. Pengujian secara statistik dilakukan hingga tingkat keyakinan $95 \%$ maka besarnya tabel $t$ adalah 2.079 Ketentuan pengambilan keputusan adalah sebagai berikut:

a. Apabila $t_{\text {hitung }}<t_{\text {tabel }}$ maka $H_{0}$ diterima dan $H_{a}$ ditolak.

b.Apabila $t_{\text {hitung }}>t_{\text {tabel }}$ maka $H_{0}$ ditolak dan $H_{a}$ diterima Hasil pengolahan data menggunakan SPSS diketahui. Hasil penelitian menunjukkan Hipotesis $1(\mathrm{H} 1)$ : Variabel nilai investasi signifikan 0,035 di peroleh $t_{\text {hitung }}$ sebesar $2.258>t_{\text {tabel }}=2.079$, maka $H_{0}$ ditolak dan $H_{a}$ diterima. dengan ini dapat disimpulkan bahwa ada pengaruh yang signifikan variabel bebas nilai investasi $\left(X_{1}\right)$ terhadap penyerapan tenaga kerja (Y). Hipotesis 2 $(\mathrm{H} 2)$ Variabel modal signifikan 0,004 diperoleh nilai $t_{\text {hitung }}=3.193>_{(0,025: 21)}=2.079$. Hingga tingkat keyakinan 95\% Maka $H_{0}$ ditolak dan $H_{a}$ diterima artinya, variabel modal $\left(\mathrm{X}_{2}\right)$ mempunyai berpengaruh signifikan terhadap penyerapan tenaga kerja (Y). Hipotesis $3(\mathrm{H} 3)$. Variabel upah 0,022 di peroleh $t_{\text {hitung }}=2.481>t_{(0,025: 21)}=2079$. Hingga tingkat keyakinan 95\% Maka $H_{0}$ ditolak dan $H_{a}$ diterima artinya, variabel upah $\left(\mathrm{X}_{3}\right)$ mempunyai berpengaruh signifikan terhadap penyerapan tenaga kerja (Y). Pengujian secara bersama (F), Uji ini bertujuan untuk mengetahui pengaruh variabel independen secara bersama-sama terhadap variabel dependent.

Ketentuan pengambilan keputusan : $H_{0}$ diterima dan $H_{a}$ ditolak apabila $F_{\text {hitung }}<F_{\text {tabel }}$, selanjutnya $H_{0}$ ditolak dan $H_{a}$ diterima apabila $F_{\text {hitung }}>F_{\text {tabel }}$. Berikut hasil uji pengaruh X1, X2, X3 terhadap Y disajikan pada tabel 4.2 berikut.

Tabel 4.2. Uji F

\begin{tabular}{rl|r|r|r|r|r}
\hline \multicolumn{1}{l|}{ Model } & Sum of Squares & Df & Mean Square & F & Sig. \\
\hline \multirow{2}{*}{1} & Regression & 425752,48 & 3 & 14197,49 & 34,650 &, $000^{\mathrm{b}}$ \\
& Residual & 532457,73 & 22 & 40950,59 & & \\
& Total & 958210,21 & 25 & & & \\
\hline
\end{tabular}

Sumber : data diolah

Hasil pengolahan data menggunakan program SPSS Tabel 4.2, sebesar nilai $F_{\text {hitung }}=34.650>3,07$. Maka dapat diambil kesimpulan bahwa $H_{0}$ ditolak dan $H_{a}$ diterima, hal ini berarti bahwa variabel independen nilai investasi $\left(X_{1}\right)$, modal $\left(X_{2}\right)$, upah $\left(X_{3}\right)$ mempunyai pengaruh yang signifikan secara bersama-sama terhadap penyerapan tenaga kerja $(\mathrm{Y})$. Koefisien determinasi $\left(\mathrm{R}^{2}\right)$ yaitu untuk mengetahui seberapa jauh proporsi variabel independen dapat menerangkan dengan baik variabel independen. Dari hasil perhitungan dari $\mathrm{R}^{2}$ dengan bantuan SPSS 20 adalah sebagai berikut:

Tabel 4.3. Hasil Koefisien Determinasi $\left(\mathbf{R}^{2}\right)$

\begin{tabular}{|c|c|c|c|c|c|}
\hline Model & $\mathrm{R}$ & R Square & Adjusted R Square & $\begin{array}{l}\text { Std. Error of the } \\
\text { Estimate }\end{array}$ & Durbin-Watson \\
\hline 1 & $.901^{\mathrm{a}}$ & .811 & .784 & .446 & 1.946 \\
\hline
\end{tabular}

Predictors: (Constant), X3, X2, X1. Dependent Variable: Y (Sumber : data diolah)

Berdasarkan hasil output SPSS Tabel 4.3 menunjukkan nilai Durbin-Watson (DW) sebesar 1,946 pengambilan keputusan memerlukan dua nilai bantu yang diperoleh dari tabel DW, yaitu DL dan DU dengan $\mathrm{K}=$ jumlah variabel independen dan $\mathrm{N}=$ banyaknya sampel (usaha) dari table 3.1 kriteria pengujian DW jika nilai DW berada antara nilai DU hingga (4-DU) berarti asumsi tidak terjadi autokorelasi terpenuhi. Berarti $\mathrm{n}=21, \mathrm{k}=$ 3 , maka diperoleh dari tabel DW yaitu nilai $\mathrm{DL}=1,026$, dan nilai $\mathrm{DU}=1,669$, sehingga nilai $4-\mathrm{DU}=4-$ $1,669=2,331$, dan nilai $4-\mathrm{DL}=4-1,026=2,974$. karena nilai DW 1,946 dapat disimpulkan bahwa $\mathrm{dU}<\mathrm{d}<4-\mathrm{dU}$ model persamaan regresi tersebut tidak ada autokorelasi.

Selanjutnya nilai koefisien determinasi $(\mathrm{R}$-square $)=0,811$ dapat di interpertasikan bahwa sebesar $81,1 \%$ variasi penyerapan tenaga kerja industri kerajinan annyaman rotan dapat dijelaskan oleh variasi nilai invesatasi $\left(\mathrm{X}_{1}\right)$, modal $\left(\mathrm{X}_{2}\right)$ dan upah $\left(\mathrm{X}_{3}\right)$, secara bersama-sama, sisanya sebesar $18,9 \%$ di pengaruhi oleh faktor-faktor lain yang tidak ikut di analisis. 


\section{Kesimpulan}

Berdasarkan analisis dan pembahasan pada penelitian ini dapat di ambil kesimpulan sebagai berikut : Investasi berpengaruh signifikan terhadap penyerapan tenaga kerja pada industri ayaman rotan di Kota Palangka Raya. Hasil penelitian yang dilakukan mengenai pengaruh upah tenaga kerja terhadap penyerapan tenaga kerja pada industri anyaman rotan di Kota Palangka Raya, diketahui bahwa secara parsial upah tenaga kerja berpengaruh negatif dan signifikan terhadap penyerapan tenaga kerja pada industri anyaman rotan di Kota Palangka Raya. Ini berarti bahwa semakin tinggi upah yang diberikan, maka semakin sedikit tenaga kerja yang diserap. Modal berpengaru signifikan terhadap penyerapan tenaga kerja pada industri ayaman rotan di Kota Palangka Raya. Upah berpengaruh signifikan terhadap penyerapan tenaga kerja pada industri anyaman rotan di Kota Palangka Raya. Berdasarkan hasil penelitian yang dilakukan mengenai pengaruh modal terhadap penyerapan tenaga kerja pada industri anyaman rotan di Kota Palangka Raya, diketahui bahwa secara parsial modal berpengaruh signifikan terhadap penyerapan tenaga kerja pada industri anyaman rotan di Kota Palangka Raya. Ini berarti bahwa semakin tinggi modal yang dimiliki industri anyaman rotan di Kota Palangka Raya, maka semakin tinggi pula penyerapan tenaga kerja yang dilakukan oleh industri tersebut. sesuai kesimpulan di atas bahwa nilai investasi berpengaruh positif terhadap penyerapan tenaga kerja, maka dalam rangka meningkatkan pertumbuhan tenaga kerja pada industri anyaman rotan di Kota Palangka Raya, maka program bantuan permodalan seperti yang sudah dilaksanakan selama ini oleh pemerintah dan BUMN masih perlu di tingkatkan lagi.

Pemerintah dalam menetapkan UMR perlu mempertimbangkan dalam penentuan kebijakan upah minimum haruslah lebih memperhatikan kebutuhan hidup buruh agar dapat hidup layak ditengah masyarakat dan sosialnya. Sehingga akan berdampak bagi kehidupannya di masa mendatang. Bagi UMKM dalam mengambil bantuan modal yang diberikan sebaiknya memerhatikan pengelolaan dari modal tersebut. Perlunya pencatatan keuangan juga mesti diperhatikan agar adanya transparansi ke berbagai pihak mengenai modal dan pendapatan. Selain itu UMKM juga perlunya memperluas usaha, sehingga tidak lagi bergantung kepada sarana yang disediakan oleh pihak pemerintah. Untuk mempermudah administrasi, sebaiknya UMKM telah terdaftar sebagai usaha yang berbadan hukum. Hasil ini dapat menjadi acuan dalam penelitian selanjutnya untuk meningkatkan kinerja industri kerajinan lainnya di Indonesia.

\section{REFERENSI}

[1] Abdi, S. (2017). Analisis Rencana Investasi Aktiva Tetap Terhadap Perluasan Usaha Pada Pt. Taspi Trd Coy Di Kota Makassar. Idaarah: Jurnal Manajemen Pendidikan, 1(2).

[2] Saputri, M. D. (2018). Analisis Pengaruh Jumlah Unit Usaha, Investasi dan Upah Minimum terhadap Penyerapan Tenaga Kerja pada Sektor Industri Pengolahan Besar dan Sedang di Kota Surabaya Tahun 2005-2014. JEB 17: Jurnal Ekonomi dan Bisnis, 3(01).

[3] Pontoh, W., \& Budiarso, N. S. (2020). Keputusan investasi pada Usaha Mikro, Kecil, dan Menengah. The Studies of Social Sciences, 2(1), 27-32.

[4] Ermawati, N., Khotimah, T., \& Nindyasari, R. (2019). Faktor-faktor yang Mempengaruhi Usaha Mikro Kecil Menengah (UMKM) dalam Pengambilan Keputusan Investasi Studi Kasus pada UMKM Batik Tulis Lasem.

[5] Mulyadi, M. B. (2018). Pengaruh Kualitas Pelayanan Perizinan Terpadu dalam Meningkatkan Investasi dan Pertumbuhan UMKM. Jurnal Hukum Mimbar Justitia, 4(1), 112-127.

[6] Hidayat, A. F., Baskara, Z. W., Werdiningsih, W., \& Sulastri, Y. (2018). Analisa kelayakan finansial usaha agroindustri abon ikan di Tanjung Karang, Kota Mataram (Financial feasibility analysis of agroindustry fish abon in Tanjung Karang Mataram City). Jurnal Ilmiah Rekayasa Pertanian dan Biosistem, 6(1), 69-75.

[7] Sari, L. P. (2019). Pengaruh struktur modal, profitabilitas dan ukuran perusahaan pada nilai perusahaan (Doctoral dissertation, STIE Indonesia Banjarmasin).

[8] Polandos, P. M., Engka, D. S., \& Tolosang, K. D. (2019). Analisis Pengaruh Modal, Lama Usaha, dan Jumlah Tenaga Kerja Terhadap Pendapatan Usaha Mikro Kecil dan Menengah di Kecamatan Langowan Timur. Jurnal Berkala ilmiah efisiensi, 19(04).

[9] Kamaludin, K. (2018). Analisis Modal Usaha Di Masyarakat Pedesaan. Syntax Literate; Jurnal Ilmiah Indonesia, 3(9), 49-60.

[10] Riawan, R., \& Kusnawan, W. (2018). Pengaruh Modal Sendiri dan Kredit Usaha Rakyat (KUR) Terhadap Pendapatan Usaha (Studi Pada UMKM di Desa Platihan Kidul Kec. Siman). Jurnal Akuntansi dan Pajak, 19(1), 31-37. 
[11] Yogiantoro, M., Komariah, D., \& Irawan, I. (2019). Effects Of Education Funding In Increasing Human Development Index. JEJAK: Jurnal Ekonomi dan Kebijakan, 12(2), 482-497.

[12] Safitri, H., \& Setiaji, K. (2018). Pengaruh Modal Usaha Dan Karakteristik Wirausaha Terhadap Perkembangan Usaha Mikro Dan Kecil Di Desa Kedungleper Kecamatan Bangsri Kabupaten Jepara. Economic Education Analysis Journal, 7(2), 792-800.

[13] Agustin, H. U., Rianto, W. H., \& Kusuma, H. (2018). Analisis Pengaruh Modal dan Tenaga Kerja Terhadap Efisiensi Produksi Genteng di Desa Sukorejo Kecamatan Gandusari Kabupaten Trenggalek. Jurnal Ilmu Ekonomi JIE, 2(2), 194-205.

[14] Wihastuti, L., \& Rahmatullah, H. (2018). Upah minimum provinsi (UMP) dan penyerapan tenaga kerja di Pulau Jawa. Jurnal Gama Societa, 1(1), 96-102.

[15] Tanti, T., \& Hariyani, T. (2018). Analisa Pengaruh Tingkat upah, Masa kerja, Usia terhadap Produktivitas Tenaga Kerja. JURNAL EKUIVALENSI, 2(1), 29-44.

[16] Mantikei, B., Usup, R. C., Sintani, L., \& Negara, D. J. (2020). The Role of Responsible Leadership in Determining the Triple-Bottom-Line Performance of the Indonesian Tourist Industry. Contemporary Economics, 14(4). 